\title{
Personal and professional development of the individual in the civil service of the Russian Federation
}

\author{
Ekaterina Nikolaevna Sepiashvili ${ }^{1}$, Tatyana Vyacheslavna Maltseva ${ }^{2 *}$,Ekaterina \\ Anatolyevna Sumina ${ }^{2}$, Natalya Nikolaevna Bashlueva ${ }^{3}$, and Mariya Andreevna Bashlueva ${ }^{4}$ \\ ${ }^{1}$ Moscow Regional Cossack Institute of Technology and Management (branch) of the Federal State \\ Budgetary Educational Institution of Higher Education "K.G. Razumovsky Moscow State University \\ of technologies and management (the First Cossack University)", Administrative and Managerial \\ Personnel, Volokolamsk, Russia \\ ${ }^{2}$ Academy of Management of the Russian Ministry of Internal Affairs of Russia, Department of \\ Psychology, Pedagogy and Organization of Work with Personnel, Moscow, Russia \\ ${ }^{3}$ Kikot Moscow University of the Ministry of Internal Affairs of Russia, Department of Socio- \\ Economic and Humanitarian Disciplines, Moscow, Russia \\ ${ }^{4}$ Kikot Moscow University of the Ministry of Internal Affairs of Russia Department of Criminal Law \\ and Criminology, Moscow, Russia
}

\begin{abstract}
The presence of professional highly qualified personnel in the civil service, together with modern information technologies, is possible thanks to the existence of a democratic state governed by the rule of law. The professional activity of civil servants acts as a subsystem within the civil service system. The study of the peculiarities of personal and professional development of the individual in the civil service will contribute to the disclosure of the psychological mechanisms of this process, the resolution of a number of pressing questions about the methods and possibilities of optimizing professional and personal development, which in turn will contribute to improving labour efficiency. To study the features of personal and professional development of the individual in the Russian Federation Civil Service. Survey among civil servants and comparative analysis of the results obtained in all study groups; statistical processing of the results. 120 respondents took part in the study: federal-state civil servants (40 people) and civil servants of other types ( 80 people). The main problems and features of personal and professional development of the individual in the civil service of the Russian Federation are identified and the main directions of optimization of the studied process are determined. The process of personal and professional development of civil servants, as will be shown in this study, is an overall result of the professional education and additional professional education, including retraining, advanced training, and internships. The main directions of optimization of the studied process are the following: improving scientific, methodological, and organizational support; increasing the motivation for professional activity and career advancement; improving the efficiency of additional professional education; developing a program for personal and professional self-development;
\end{abstract}

\footnotetext{
* Corresponding author: mtv-psy@mail.ru
} 
introducing additional forms and technologies for improving professional skills of state civil servants.

Keywords: personal development, professional psychology, job satisfaction

\section{Introduction}

The beginning of the 21th century is marked in Russia by the formation of the civil service system (hereinafter-the Civil Service), which is key to creating core expertise in all types of the state personnel.

The signing of the Federal Law No. 58-FZ under the date of May 27, 2003 "On the Civil Service System of the Russian Federation" [1] played an important role in the formation and further development of the Civil Service institute in modern Russia. The normative consolidation of service types, as well as the basic principles of construction and functioning of the system of the Russian Federation (hereinafter referred to as the Russian Federation) State Civil Service, allows us to talk about the creation of state civil servants corps with certain personal characteristics and professional competencies that are necessary for the efficient functioning of executive authorities.

The very existence of a democratic state governed by Law makes it necessary to have professional, highly qualified personnel at the CS to use modern information technologies.

The signing of Decree No. 288 of June 24, 2019 "On the main directions of development of the State Civil Service of the Russian Federation for 2019-2021 period" [2] by the President of the Russian Federation is aimed at improving the procedure of appointing citizens and state civil servants to positions at the state civil service, encouraging civil servants to improve the efficiency of their professional performance, developing the system of state legal and social guarantees in the civil service, introducing new forms of professional development of civil servants, including the use of information and communication technologies and their accelerated implementation in federal executive bodies in order to improve the quality of personnel work. Thus, the personal and professional development of civil servants comes to the fore.

The professional activity of state civil servants, their professional path acts as a subsystem within the civil servants system. The study of the peculiarities of personal and professional development of the individual in the CS will contribute to answering a number of questions about the methods and opportunities for the efficiency of professional and personal development, about psychological mechanisms for improving labour efficiency.

The hypothesis of the study was the assumption that the success of personal and professional development of the individual in the CS affects the efficiency of their work, the development of professionalism and the life of the individual as a whole. The aim of the study was to gather empirical evidence about the features of this process in the individual working at the CS of different types, but also to determine the main directions of its optimization.

\section{$2 \quad$ Methods}

In order to study civil servants' personal and professional development, the authors questioned them; a comparative analysis of the answers obtained in study groups and statistical processing was carried out.

In the study, 120 respondents took part: federal-state civil servants (40 people) and civil servants of other types ( 80 people). 
The questionnaire had 15 questions in total. They were grouped into four semantic blocks: "personal" questions; questions about working conditions in the public service; their attitude to the public service; the image they have about their work.

\section{$3 \quad$ Results}

The group of respondents consisted of the following people. The study involved 85 men (70.8\%) and 35 women (29.2\%), of which: more than $60 \%$ - employees of the state service of other types, $33 \%$ - federal-state civil servants.

The study of the education level (Fig. 1) showed that a larger percentage of respondents have higher education and to a much lesser degree - secondary vocational and general secondary education. At the same time, it should be noted that respondents with secondary vocational and general secondary education are $100 \%$ in the $25-30$-year age group.

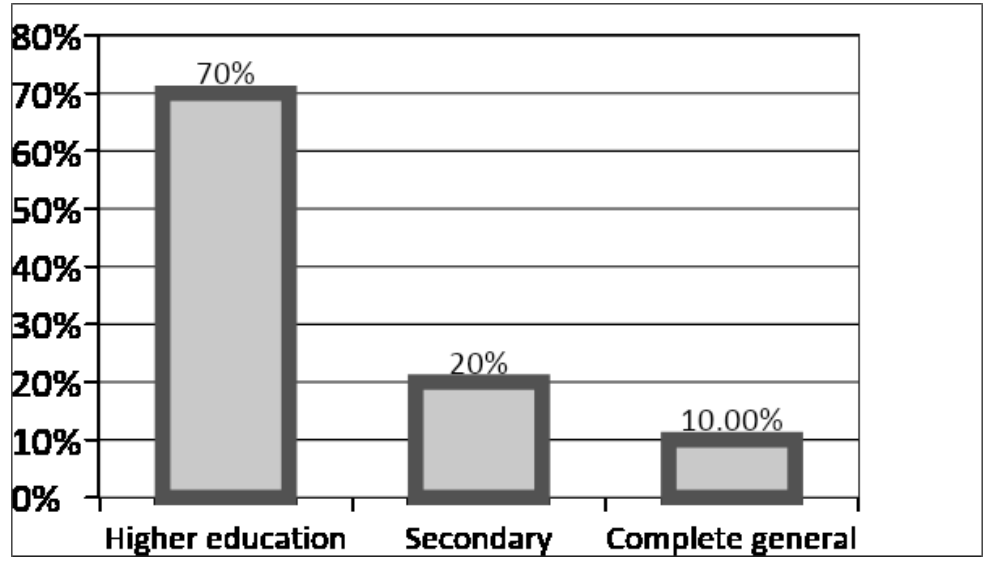

Fig. 1. The level of education among respondents.

Figure 2 shows the experience of the CS in the comparison between federal-state civil servants and employees of other types of civil service. When analysing the data, it should be concluded that employees of other types of civil service for the most part do not have work experience before starting their service, and federal-state civil servants at the time of admission to the CS forces already have work experience. At the same time, $80 \%$ of federalstate civil servants do not change their place of service, and $70 \%$ of civil service employees of other types have moved to other places of service. 


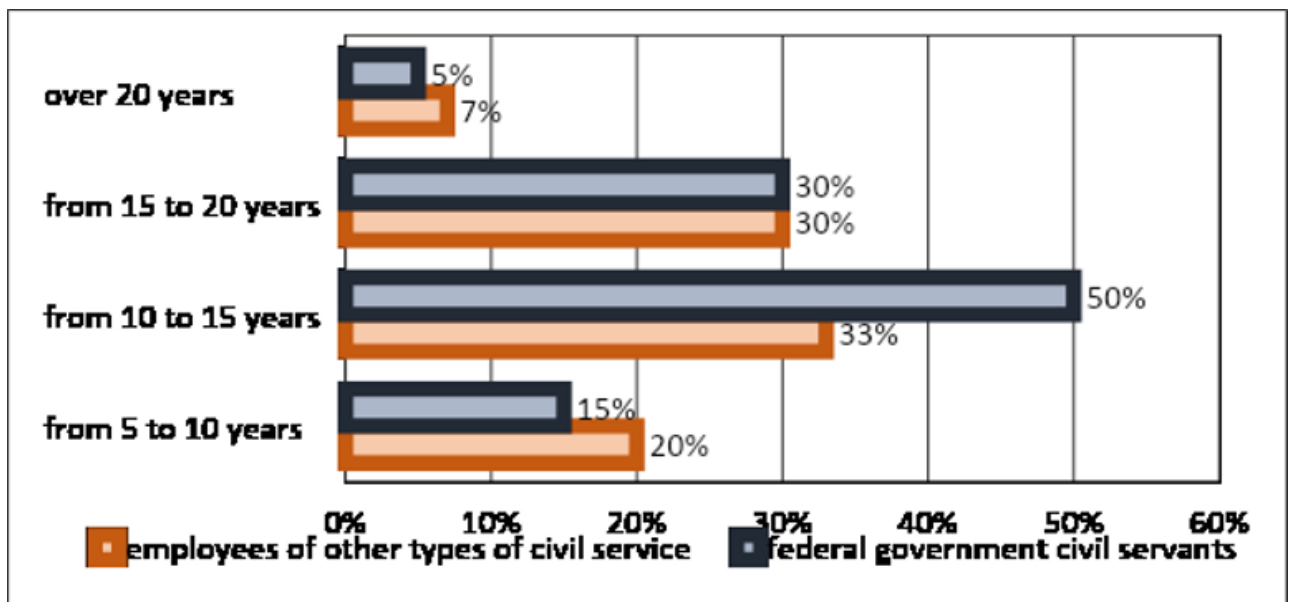

Fig. 2. Public service experience.

Figures 3 and 4 illustrate the desire to consciously become a civil servant - most civil servants simply chose a suitable job for themselves, while other types of civil servants consciously sought to serve their country.

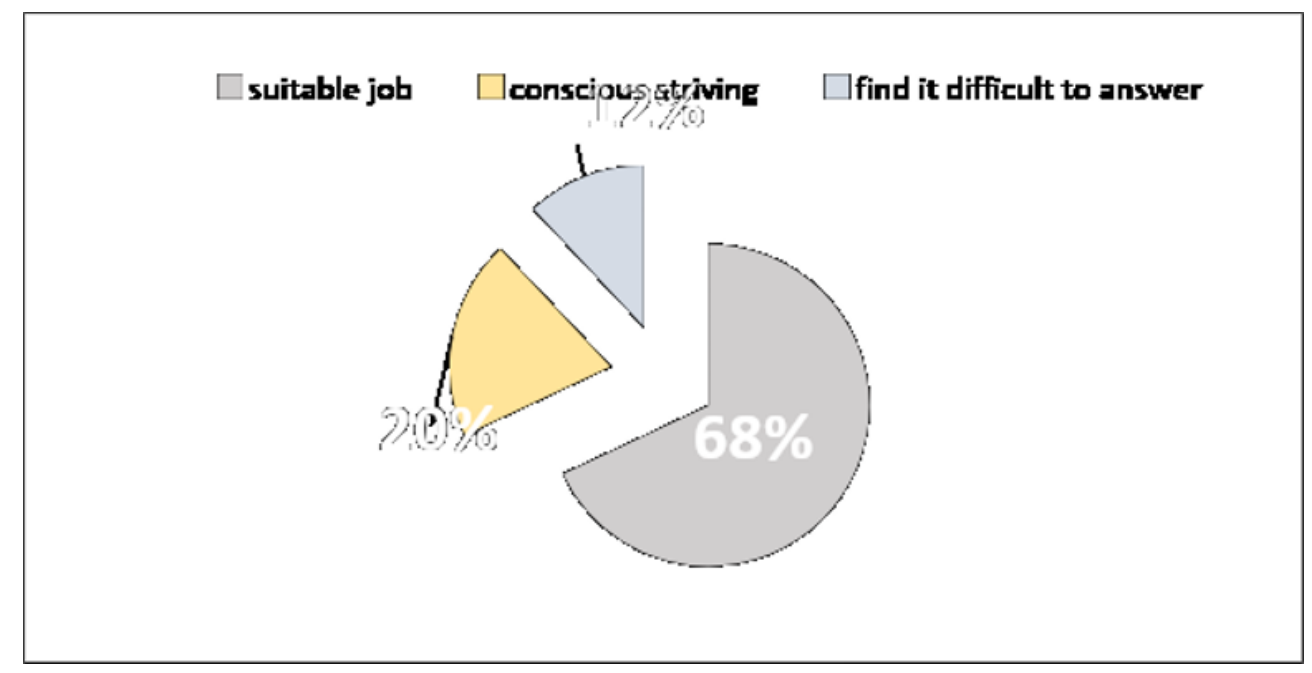

Fig. 3. Consciousness of choice of federal public civil servants. 


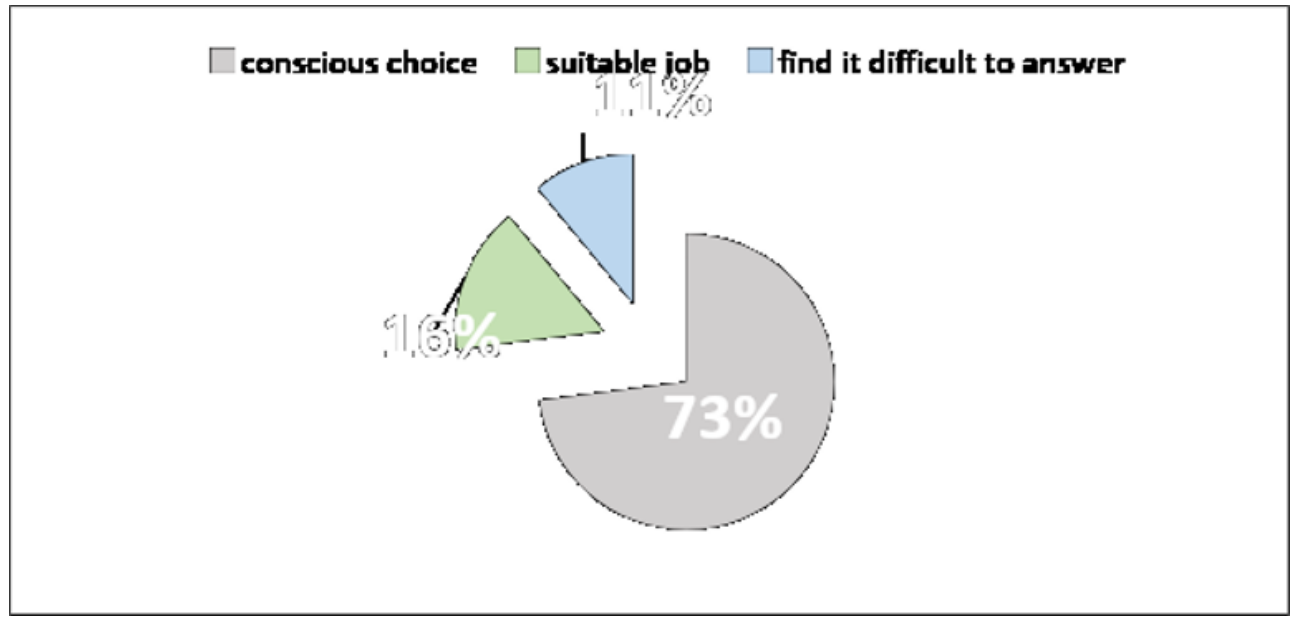

Fig. 4. Consciousness of choice of civil service employees of other types.

When studying working values, the respondents' opinions were distributed as follows (Fig. 5). More than half of the respondents' value working in CS for stability and job security, as well as the availability of connections and additional social benefits and guarantees. Only a small percentage of respondents considered CS an interesting job where one can earn good money with a convenient working day schedule.

The block of questions was devoted to the study of the attitude towards CS. So $80 \%$ of respondents consider the civil service rather prestigious than not, $15 \%$ - rather not prestigious than prestigious, $5 \%$ consider the CS not prestigious at all. All respondents think about changing their professional activities and/or switching to business projects, with $28 \%$ admitting that they think about it often, while others think about it from time to time. Only $23 \%$ of respondents are ready to move from place to place for career growth, salary increase (in the service, with the provision of employer-rented housing), to change the region at least once every 3-4 years. 


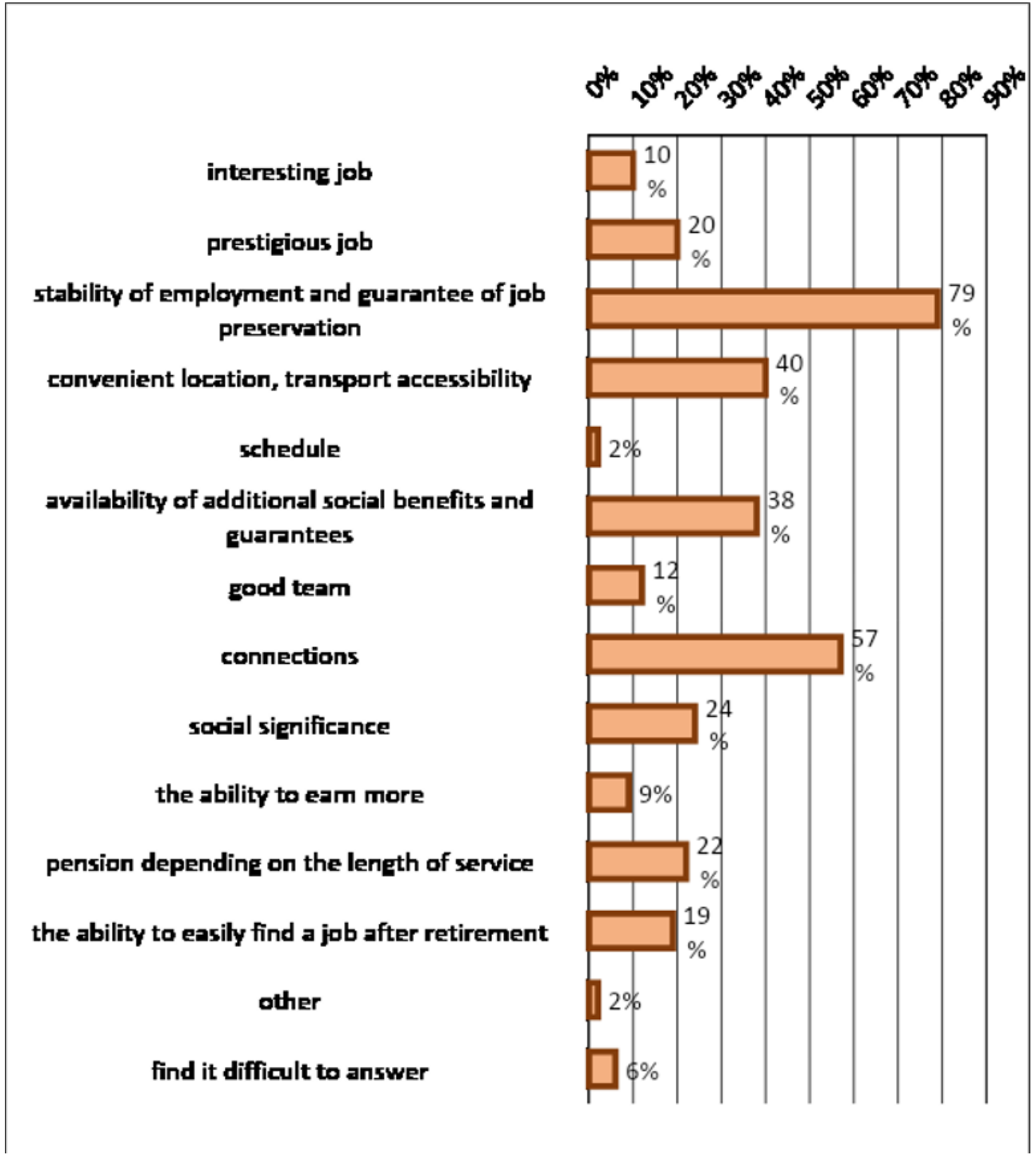

Fig. 5. Performance values.

The respondents were also asked questions about their professional and career growth (Figures 6, 7 and 8). Based on the responses, it should be concluded that all employees of other types of civil service are involved in internal internships, and the vast majority have already participated in additional training programs. Unfortunately, such forms of professional development as international internships, seminars, and training courses are often not used in the federal executive authorities.

When answering the question about the benefits of participating in additional professional training, retraining, and/or advanced training programs, most respondents chose the following answers: "I have significantly broadened my horizons" and "I have learned about the latest trends and current (international) experience in a particular field." 


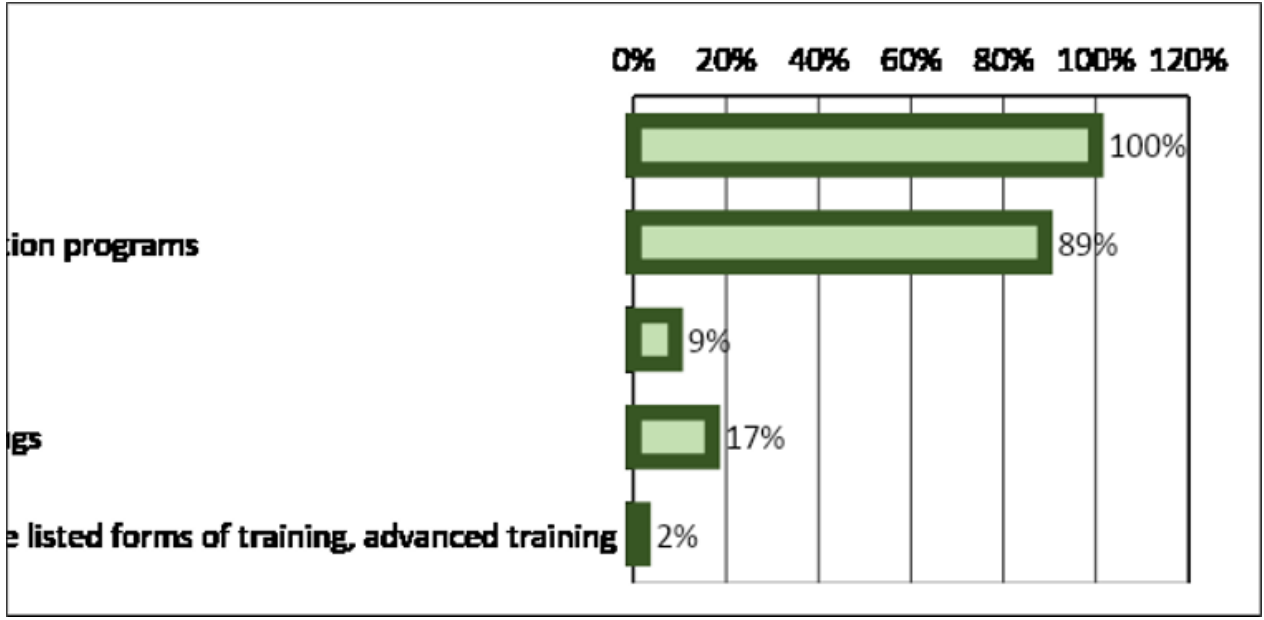

Fig. 6. Participation in the forms of professional development.

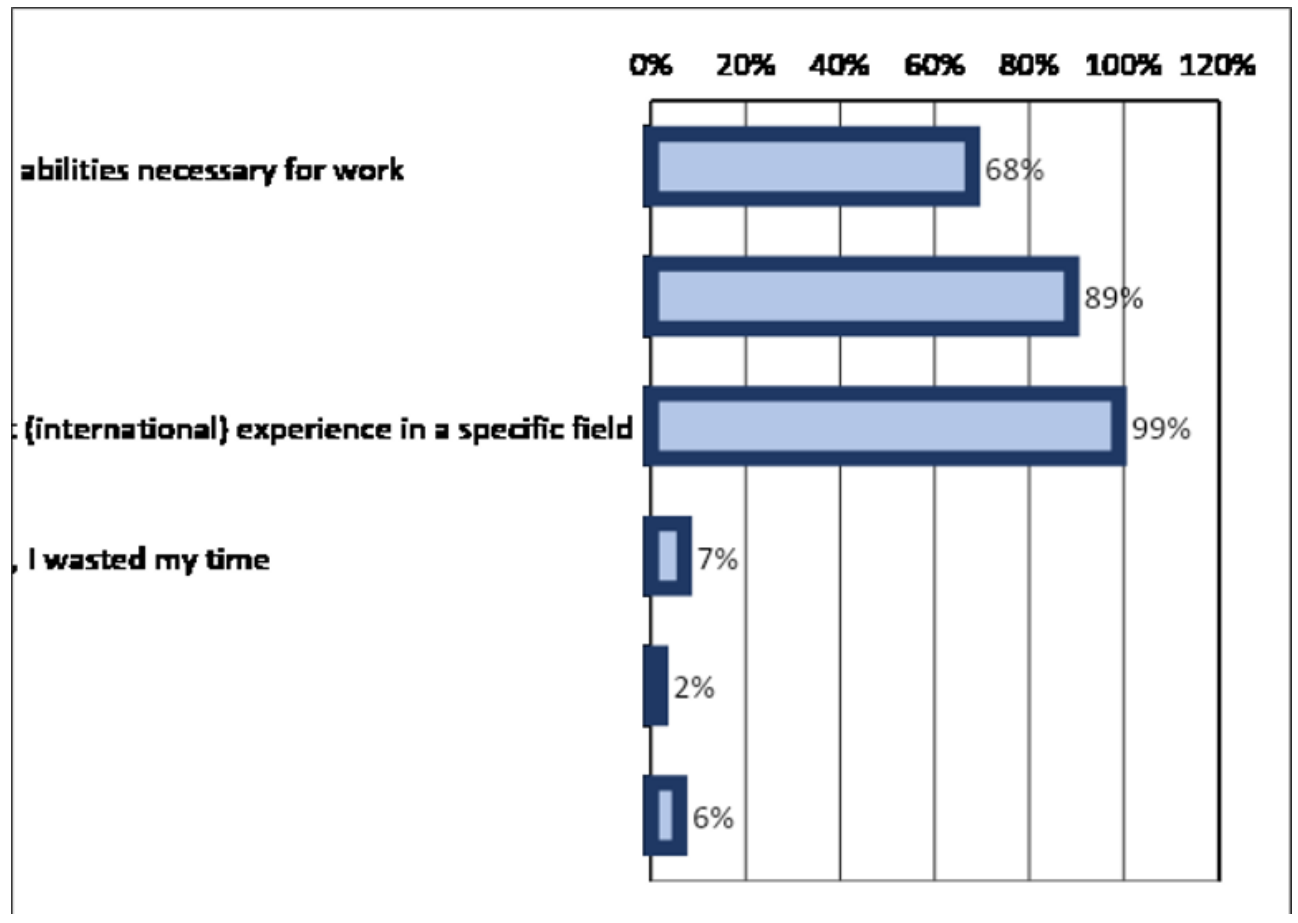

Fig. 7. Opinion on the results of professional development programs.

Also, the majority of respondents believe that professional development programs provide the development of necessary professional competencies.

The respondents answered about the predictability of the conditions of career growth, depending on the type of CS. They are considered certain and understandable by employees in other types of civil service. However, federal public civil servants mostly see this dependence on the state body head, only a fourth of public civil servants see the conditions for their career as defined and understandable. 


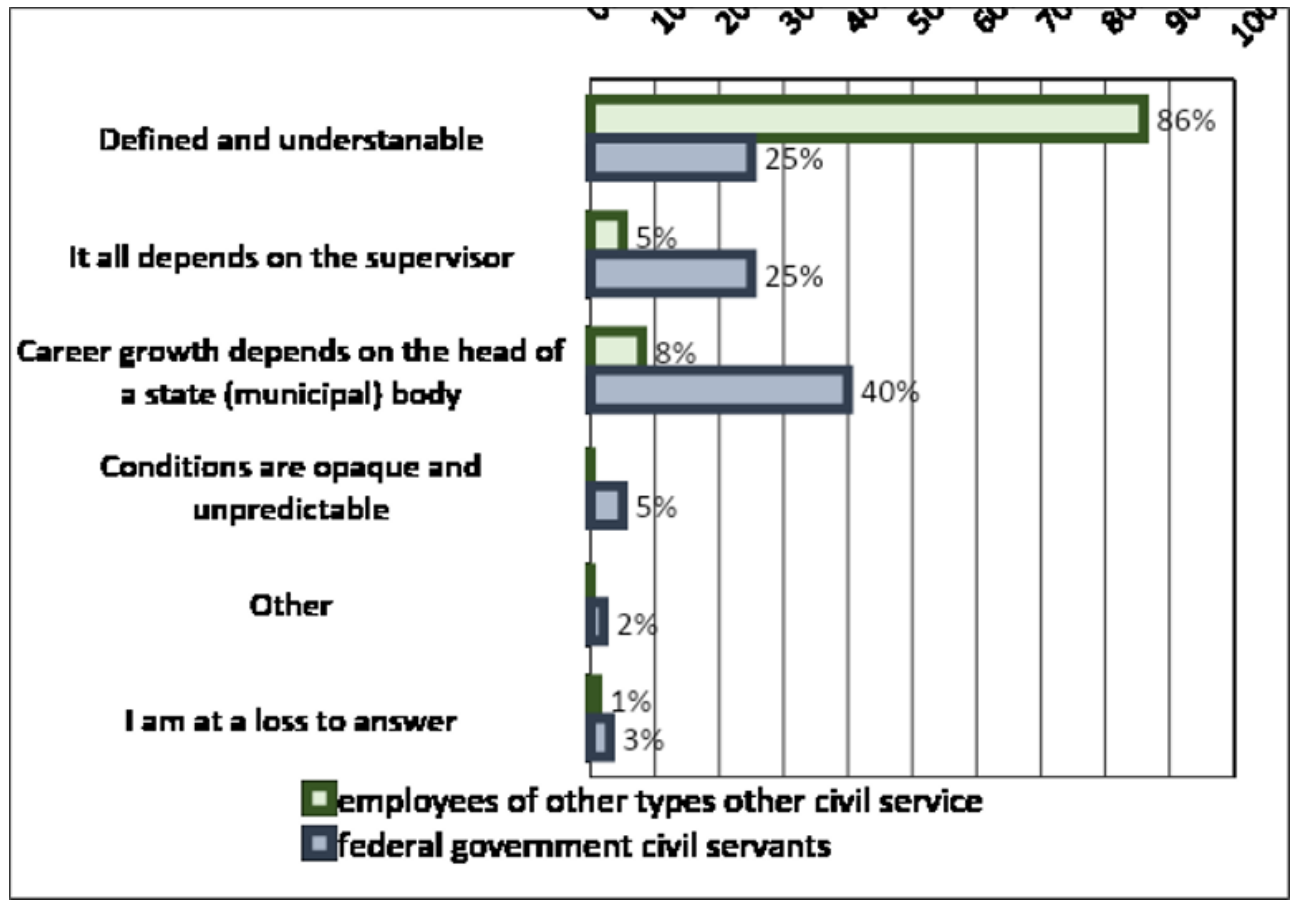

Fig. 8. Opinion on career growth.

\section{Discussion}

Questions on the personal and professional development of the individuals in the Russian Federation Civil Service can be found in the scientific works of Shadrikov [3], Shepel [4], which paid attention to the study of the essence of professional development in the field of public administration, Atamanchuk, Matirko [5], Ignatova, Kozachok, Pashin [6], Korostyleva [7], who study the professionalism and professionalization of state civil servants, Dyachkov [8], Isaev [9], who studied the factors of professional development in the field of public administration, Mogilevkin [10], Shevel [11], who studied the personal qualities of civil servants necessary for professional development and career growth, Derkach [12], Zeer [13], who analyzed this process from the point of view of psychological and acmeological approaches, Miroshnikov, Charkina [14], Parkhomenko-Kutsevil [15] who addressed the problem professional education of civil servants. A broad monographic study of the psychological problems of professional formation of civil servants was conducted by Akimova [16], and Bushueva [17] studied management issues of professional development of state civil servants.

At the moment, the problem of personal and professional development of the individual in the CS is actively covered in scientific works of both Russian and foreign authors: Kruyen, Genugten [18], Knies, Boselie, Goud-Williams, and Vandenabeele [19], Kozhanov, Maltseva [20], Chetverikova, Kolmykova [21], Bashurov [22], Gorach et al. [23], Wang et al. [24].

Having analyzed the results of this study researchers found that these results do not contradict the data obtained in the above-mentioned studies, but complements them taking into account the current stage of development of the civil service. 


\section{Conclusion}

The authors are set to determine the main problems and directions of optimizing the personal and professional development of the individual in Russian CS. Among the main problems of personal and professional development of civil servants, which can also act as features of their professional development, the following are identified:

- insufficient scientific, methodological, and organizational support for the personal and professional development of civil servants;

- low motivation and weak connection between professional development and career advancement;

- lack of effective mechanisms for continuing professional education;

- HR and psychological services advisors do not pay enough attention to the organization of personal and professional development of civil servants, do not have sufficient authority, and are not responsible for the organization and control of their professional development;

- additional forms and technologies for improving the skills of civil servants are being introduced with lots of issues.

The process of personal and professional development of civil servants, as shown by the study, is an overall result of the professional education and additional professional education, including professional retraining, advanced training, and internships.

\section{References}

1. O sisteme gosudarstvennoy sluzhby Rossiyskoy Federatsii: feder. Zakon Ros. Federatsii [The Federal Law No. 58-FZ dd. 27 May 2003, "On the System of Public Service in the Russian Federation" [Online]. Access from the ConsultantPlus Legal Reference System. Available: http://www.consultant.ru/document/cons_doc_LAW_42413/

2. Ukaz Prezidenta RF “Ob osnovnykh napravleniyakh razvitiya gosudarstvennoy grazhdanskoy sluzhby RF [Decree of the President of the Russian Federation No. 288 under date of June 24, 2019 "On the main directions of development of the State Civil Service of the Russian Federation for 2019-2021"] [Online]. Access from the ConsultantPlus Legal Reference System. Available: http://www.kremlin.ru/acts/bank/44367

3. V.D. Shadrikov, Problemy sistemogeneza professionalnoy deyatelnosti [Problems of the systematic genesis of professional activities] (Nauka Publ., Moscow, 1982)

4. V.M. Shepel, Nastolnaya kniga biznesmena i menedzhera: upravlencheskaya gumanitarologiya [Businessman's Handbook: managerial humanitarian studies] (Finansy i Statistika, Moscow, 1992)

5. S.G. Atamanchuk, V.I. Matirko, Gosudarstvennaya sluzhba: kadrovyi potentsial [Public service: Human Resources Potential: textbook] (Delo Publ., Moscow, 2001)

6. T.V. Ignatova, V.I. Kozachok, L.A. Pashin, Mid-Russian Bulletin of Social Sciences, 6, 34 (2015)

7. N.N. Korostyleva, Bulletin of Povolzhsky Institute of Management named after P.A. Stolypin, 2(41), 58 (2014)

8. V.M. Dyachkov, Optimizatsiya lichnostno-professionalnogo razvitiya gossluzhashchikh regionalnogo upravleniya [Optimization of personal and professional development of civil servants of regional state authorities], $\mathrm{PhD}$ thesis of Psychological Sciences (Moscow, 1997) 
9. Z.E. Isaev, Sotsialnye aspekty professionalnogo razvitiya kadrov gosudarstvennoi grazhdanskoi sluzhby [Social aspects of professional development of civil service personnel], $\mathrm{PhD}$ thesis of Social Sciences (Moscow, 2004)

10. E.A. Mogilevkin, Lichnostnye faktory professionalnoi karery gosudarstvennykh sluzhashchikh [Personal factors of civil servants' professional careers], $\mathrm{PhD}$ thesis of Psychological Sciences (Moscow, 1998)

11. P.P. Shevel, Social and Humanitarian Knowledge, 2, 330 (2012)

12. A.A. Derkach, Acmeology, 2, 9 (2013)

13. E.F. Zeer, Psikhologiya professionalnogo razvitiya [Psychology of Professional Development] (Izdat. Tsentr "Akademiya", Moscow, 2009)

14. S.N. Miroshnikov, E.S. Charkina, Managerial Consulting, 1(97), 12 (2017)

15. O.I. Parkhomenko-Kutsevil, Public Management, 1(6), 146 (2017)

16. E.Y. Akimova, Problemy psikhologii professionalnogo stanovleniya gosudarstvennykh sluzhashchikh [Psychological Problems of Civil Servants' Professional Formation] (Print-Service LLC, Rybinsk, 2011)

17. I.P. Bushueva, Upravlenie professionalnym razvitiem gosudarstvennykh grazhdanskikh sluzhashchikh: regionalnyi aspekt [Managing professional development of state civil servants: regional aspect], $\mathrm{PhD}$ thesis of Social Sciences (Nizhny Novgorod, 2015)

18. P.M. Kruyen, M. Van Genugten, Public Management Review, 22(1), 118 (2020). https://doi.org/10.1080/14719037.2019.1638442

19. E. Knies, P. Boselie, J. Goud-Williams, W. Vandenabeele, The International Journal of Human Resource Management (2018). https://doi.org/10.1080/09585192.2017.1407088

20. E.K. Kozhanov, T.V. Maltseva, Applied Psychology and Pedagogy, 1, 1 (2019). https://doi.org/10.12737/article_5c2cf58e35fe09.71974678

21. N.A. Chetverikova, M.A. Kolmykova, University Bulletin, 9, 33 (2019). https://doi.org/10.26425/1816-4277-2019-9-33-38

22. V.B. Bashurov, Siberian Law Review, 16, 389 (2019). https://doi.org/10.19073/26587602-2019-16-3-389-395

23. N.N. Gorach, T.V. Maltseva, A.S. Semchenko, E.A. Sumina, S.A. Khmelev, E.A. Trishkina, S.N. Belova, International Journal of Recent Technology and Engineering, 8(4), art. 12667 (2019). https://doi.org/10.35940/ijrte.D9071.118419

24. Y. Wang, J. Fang, Scientific and Social Research, 2(2) (2020). https://doi.org/10.36922/ssr.v2i2.953 